Article

\title{
Energy and Protein in Critically Ill Patients with AKI: A Prospective, Multicenter Observational Study Using Indirect Calorimetry and Protein Catabolic Rate
}

\author{
Alice Sabatino ${ }^{1}$ (D), Miriam Theilla ${ }^{2}$, Moran Hellerman ${ }^{2}$, Pierre Singer ${ }^{2}$, Umberto Maggiore $^{3}$, \\ Maria Barbagallo ${ }^{4}$, Giuseppe Regolisti ${ }^{1}$ and Enrico Fiaccadori ${ }^{1, *}$ \\ 1 Acute and Chronic Renal Failure Unit, Department of Clinical and Experimental Medicine Renal ICU, Parma \\ University Hospital, Parma 43126, Italy; alice.sabatino86@gmail.com (A.S.); giuregolisti@gmail.com (G.R.) \\ 2 Department of General Intensive Care and Institute for Nutrition Research, Rabin Medical Center, Beilinson \\ Hospital, Petah Tikva, Affiliated with the Sackler School of Medicine, Tel Aviv University, Tel Aviv 49100, \\ Israel; miriamt@clalit.org.il (M.T.); moranhe@clalit.org.il (M.H.); psinger@clalit.org.il (P.S.) \\ 3 Kidney-Pancreas Transplant Unit, Parma University Hospital, Parma 43126, Italy; \\ umberto_maggiore@hotmail.com \\ 4 Surgical ICU, Anesthesia, Intensive Care and Pain Therapy, Parma University Hospital, Parma 43126, Italy; \\ mbarbagallo@parmanesthesia.com \\ * Correspondence: enrico.fiaccadori@unipr.it; Tel.: +39-052-170-2367
}

Received: 12 June 2017; Accepted: 21 July 2017; Published: 26 July 2017

\begin{abstract}
The optimal nutritional support in Acute Kidney Injury (AKI) still remains an open issue. The present study was aimed at evaluating the validity of conventional predictive formulas for the calculation of both energy expenditure and protein needs in critically ill patients with AKI. A prospective, multicenter, observational study was conducted on adult patients hospitalized with AKI in three different intensive care units (ICU). Nutrient needs were estimated by different methods: the Guidelines of the European Society of Parenteral and Enteral Nutrition (ESPEN) for both calories and proteins, the Harris-Benedict equation, the Penn-State and Faisy-Fagon equations for energy. Actual energy and protein needs were repeatedly measured by indirect calorimetry (IC) and protein catabolic rate (PCR) until oral nutrition start, hospital discharge or renal function recovery. Forty-two patients with AKI were enrolled, with 130 IC and 123 PCR measurements obtained over 654 days of artificial nutrition. No predictive formula was precise enough, and Bland-Altman plots wide limits of agreement for all equations highlight the potential to under- or overfeed individual patients. Conventional predictive formulas may frequently lead to incorrect energy and protein need estimation. In critically ill patients with AKI an increased risk for under- or overfeeding is likely when nutrient needs are estimated instead of measured.
\end{abstract}

Keywords: acute kidney injury; artificial nutrition; indirect calorimetry; overfeeding; protein catabolic rate; underfeeding

\section{Introduction}

Acute Kidney Injury (AKI) is now considered a major clinical health problem [1,2]. In fact, its incidence is increasing, especially among ICU patients, and the syndrome still remains associated with highly negative outcomes [3,4]. Severe malnutrition has been documented in up to $40 \%$ of patients with AKI, and is associated with a further increase in the mortality risk and complications [5].

Accurate determination of protein and energy needs is obviously important in this clinical setting, because both over- and underfeeding may occur and are associated with poor outcomes $[6,7]$. In particular, significant underfeeding has been recently documented in a recent re-analysis of data 
from a large cohort of patients with AKI from the RENAL study, whose average daily calorie and protein intake was respectively $867 \mathrm{kcal}$ and $34.8 \mathrm{~g}$ [8].

The gold standard for measuring individual caloric needs is represented by indirect calorimetry (IC), a noninvasive method allowing resting energy expenditure (REE) assessment based on oxygen consumption and carbon dioxide production measurements in the exhaled air [9]. In critically ill patients, REE measured by IC is in general considered for nutritional prescription. However, during the very early phase (2-3 days) of an acute illness the body produces enough amount of energy to cover most of energy needs, increasing the risk for early overfeeding [9]. Regarding proteins, the daily protein catabolic rate (PCR as $\mathrm{g} / 24 \mathrm{~h}$ ) reflects the amount of protein undergoing catabolism and could be considered the target for protein prescription. PCR can be derived from cumulative nitrogen excretion and urea kinetics, in the case of Renal Replacement Therapy (RRT), and can also be expressed as normalized PCR (nPCR, as g/ $\mathrm{kg}$ of BW/24 h) [10]. Unfortunately, IC measurements and nPCR are not widely used in daily ICU routine [9], due to time constraints, reduced equipment availability, staffing scarcity, and costs [9]. On the other hand, the important limitations and the lack of accuracy of conventional predictive equations for EE estimation in critically ill are well known [11-15]. Moreover, data on their validity when applied to patients with AKI are scanty [16]. Regarding proteins, while PCR of patients on RRT has been investigated in the past by urea kinetic methods [10,17-21], no data are currently available on PCR in patients with AKI not on RRT.

Thus, the purpose of our study in patients with AKI with or without RRT need was:

(a) to evaluate the validity of conventional predictive formulas and equations for the calculation of energy expenditure and protein needs, by using IC and the nPCR as gold standards;

(b) to compare prescribed and actually received nutrients with estimated and measured needs.

\section{Materials and Methods}

\subsection{Patients}

This prospective observational study was conducted at the Renal and the Surgical ICUs of the Parma University Hospital (Parma, Italy) and at the General ICU of the Rabin Medical Center Beilinson Hospital (Tel Aviv, Israel) from October 2014 to November 2015. The procedures followed were in accordance with the Helsinki Declaration. The local Institutional Review Boards approved the study. Written informed consent was obtained from the patients, or from an authorized next of kin/legal representative.

Adult patients with stage 3 AKI [22], were included, with or without mechanical ventilation need, on exclusive artificial nutrition (enteral and/or parenteral) at the time of the first IC, and expected to have an ICU stay of at least 3 days. Exclusion criteria were based both on specific comorbidities and on the presence of factors that could interfere with REE measurements accuracy [9]. Patients with end-stage renal disease (ESRD) on chronic dialysis or peritoneal dialysis, severe liver failure, pregnancy, head trauma and burns were also excluded.

\subsection{Data Collection and Calculations}

General demographic and clinical variables were collected. Daily nutritional prescriptions and intakes were recorded up to the end of ICU stay or the beginning of oral feeding. Energy needs were estimated according to ESPEN guidelines for critically ill patients with AKI ( 25 total $\mathrm{kcal} / \mathrm{kg}$ body weight (BW)) [23,24], and from the calculated Resting Energy Expenditure (REE) values obtained by 3 different equations widely used in the ICU setting: the Faisy-Fagon [12] and the Penn-State equations [13] for mechanically ventilated patients, and the Harris-Benedict equation [25]. The detailed equations are described in the Supplementary Table S1. Protein needs were estimated according to ESPEN guidelines for critically ill patients with AKI $(1 \mathrm{~g} / \mathrm{kg} /$ day for patients not on RRT and $1.7 \mathrm{~g} / \mathrm{kg} /$ day for patients undergoing RRT) [23,24]. Actual energy needs were measured by IC every $48 \mathrm{~h}$ during the first week of study, and then once a week until beginning of oral feeding, recovery of renal function or the end of ICU stay. Normalized protein catabolic rate was calculated as previously described in detail $[10,26]$. 


\subsection{Indirect Calorimetry Instrumentation and Measurements}

The portable Vmax ${ }^{\mathrm{TM}}$ Encore Metabolic Cart 29n (SensorMedics Italia srl, Milano, Italy) or the Deltatrac II (Datex-Omeda, GE, Helsinki, Finland) were used for IC measurements. Before each measurement, flow sensor and gas calibration were performed with a fixed gas concentration. The IC measurements were performed in the morning, at a non-fasting steady state, at least $2 \mathrm{~h}$ after any intervention for a $30 \mathrm{~min}$ period. Reference weight was measured by electronic bed scales. In patients on RRT, IC measurements were performed in the interdialytic period, at least two hours after the end of dialysis. In addition, on the day of indirect calorimetry measurement additional variables that could impact on metabolism were collected (i.e., body temperature, vasoactive drugs, sedatives).

\subsection{Artificial Nutrition}

No changes were made in the routine of nutritional support for the patients, as per the protocol of each ICU. Enteral nutrition was the first choice if no major contraindication was present. Parenteral nutrition was added in case estimated needs were not reached in 3 days.

\subsection{Reference Body Weight}

As per protocol of the ICUs involved, reference BW used for the prediction of energy and protein needs was preferably measured using electronic bed scales. In the case of patients undergoing RRT, the BW measured at the end of RRT was used, while for patients not on RRT the most recent BW before IC measurement was considered for calculations. BW at admission was used only when no data on recent $\mathrm{BW}$ were available.

\subsection{Statistical Analysis}

Results are expressed as mean and standard deviation for continuous variables with normal distribution, or median and range for non-parametric data, and as frequencies for categorical variables. The pairwise differences between means of the total prescribed and delivered energy and proteins were tested by paired $t$ test or Wilcoxon for non-parametric variables. Difference between predictive equations, prescribed and delivered energy/proteins and IC/PCR values were tested with one-way ANOVA; differences between the means of each equation with IC measurements were tested by Wilcoxon for non-parametric variables. Normality was assessed with the Kolmogorov-Smirnov test. Agreement between methods was assessed by the Bland-Altman approach [27]. To consider an equation accurate, limits of agreement should be $\pm 10 \%$ of REE or $\pm 250 \mathrm{Kcal}$ [16,28-30]. Patients who achieved intakes within $90-110 \%$ of calculated targets $( \pm 10 \%$ of REE) were considered as "adequately fed". To analyze precision, we considered that if the majority ( $>50 \%$ ) of individual differences were outside the defined range considered as "adequately fed", the method was considered imprecise and clinically unacceptable. A linear mixed model was used to compare REE measured by indirect calorimetry performed at least twice in the same patients within 7 days since ICU admission. Data analysis was performed using GraphPad Prism version 6.00 for Windows (GraphPad Software, La Jolla, San Diego, CA, USA) and SPSS statistics for Windows (Version 23, IBM Corp., Armonk, NY, USA).

\section{Results}

Demographic and clinical data are described in Table 1. We enrolled 42 critically ill patients, $72 \%$ $(31 / 42)$ were male, mean age was $67( \pm 15)$ years, BMI at admission $29( \pm 9.4) \mathrm{kg} / \mathrm{m}^{2}$ (Table 1). Length of ICU stay (LOS) was 17 (5-99) days, hospital LOS was 41 (5-137) days; 24\% (10/42) of patients died during ICU stay, while the in-hospital mortality was 38\% (16/42); patients were mechanically ventilated for 12 (1-84) days. Forty-five percent (19/42) of patients needed RRT; Sustained-low efficiency dialysis (SLED, 8-12h) was performed in 14/19 (74\%) patients, continuous veno-venous hemofiltration (CVVH) in 2/19 (20\%), conventional hemodialysis in 3/19 (16\%). During the 130 IC measurements, the number of RRT treatments in the last $24 \mathrm{~h}$ before measurements corresponded 
to 38, and SLED was the most used modality (32/38, 84\%) (Table 1). Median duration of RRT was 9 (1-86) days; 6 out 19 patients (32\%) were still on RRT at ICU discharge/death. Clinical data on the day of IC measurement are described in Table 2. The average maximum temperature achieved in the last $24 \mathrm{~h}$ before IC measurement was $37( \pm 0.9){ }^{\circ} \mathrm{C}$, and the majority of patients $(57 \%)$ were using sedative drugs.

Table 1. Demographic and clinical characteristics $(n=42)$.

\begin{tabular}{|c|c|}
\hline \multicolumn{2}{|l|}{ At ICU Admission } \\
\hline Age (SD) & $67(15)$ \\
\hline Male sex (\%) & $31 / 42(72)$ \\
\hline Body weight at admission (kg) (SD) & $83(25.9)$ \\
\hline BMI (SD) & $29(9.4)$ \\
\hline APACHE II (SD) & $22.4(7.0)$ \\
\hline \multicolumn{2}{|l|}{ SOFA score (median (range)) } \\
\hline - Circulatory & $3.0(0-4)$ \\
\hline - Coagulation & $1.0(0-3)$ \\
\hline - Liver & $0.0(0-3)$ \\
\hline - Renal & $2.0(0-4)$ \\
\hline - Neurologic & $0.0(0-4)$ \\
\hline - Respiratory & $3.0(0-4)$ \\
\hline - Total & $9.1(3.2)$ \\
\hline \multicolumn{2}{|l|}{ Source of admission (\%) } \\
\hline - Other hospital & $1 / 42(2)$ \\
\hline - Medical ward & $11 / 42(26)$ \\
\hline - Surgical ward & $15 / 42(36)$ \\
\hline - Other ICUs & $7 / 42(17)$ \\
\hline - Emergency room & 8/42 (19) \\
\hline \multicolumn{2}{|l|}{ ICU admission main diagnosis (\%) } \\
\hline - Trauma & $3 / 42(7)$ \\
\hline - Septic Shock & $12 / 42(29)$ \\
\hline - Respiratory & $7 / 42(17)$ \\
\hline - Oncological & $1 / 42(2.25)$ \\
\hline - Cardiac & $1 / 42(2.25)$ \\
\hline - Intoxication & $1 / 42(2.25)$ \\
\hline - Renal & $5 / 42(12)$ \\
\hline - Vascular & 6/42 (14) \\
\hline - Gastrointestinal & $5 / 42(12)$ \\
\hline - Other & $1 / 42(2.25)$ \\
\hline \multicolumn{2}{|l|}{ Admission type (\%) } \\
\hline - Elective surgery & $3 / 42(7)$ \\
\hline - Urgent surgery & $19 / 42(45)$ \\
\hline - Medical & $20 / 42(48)$ \\
\hline \multicolumn{2}{|l|}{ Chronic comorbidities (\%) } \\
\hline - Hypertension & $31 / 42(74)$ \\
\hline - Diabetes & $16 / 42(38)$ \\
\hline - COPD & $6 / 42(14)$ \\
\hline - CAD & $6 / 42(14)$ \\
\hline$-\mathrm{CHF}$ & $7 / 42(17)$ \\
\hline - Peripheral vascular disease & 6/42 (14) \\
\hline - Immunocompromised & $4 / 42(10)$ \\
\hline - Liver disease & $5 / 42(12)$ \\
\hline - Malignancy & $4 / 42(10)$ \\
\hline - CKD (no dialysis) & $7 / 42(17)$ \\
\hline \multicolumn{2}{|c|}{ Acute comorbidities \% (at admission or up to $24 \mathrm{~h}$ from admission) } \\
\hline - Severe sepsis/septic shock & $16 / 42(38)$ \\
\hline - IMV & $31 / 42(71)$ \\
\hline - NIMV & $1 / 42(2)$ \\
\hline - Shock & $8 / 42(19)$ \\
\hline - AKI & $31 / 42(71)$ \\
\hline - Oliguria & $18 / 42(40)$ \\
\hline - RRT & $6 / 42(14)$ \\
\hline - ARDS & $11 / 42(26)$ \\
\hline - Vasoactive drugs & $20 / 42(48)$ \\
\hline - Major bleeding ( $\geq 3$ units blood needed) & $7 / 42(17)$ \\
\hline
\end{tabular}


Table 1. Cont.

\begin{tabular}{lc}
\hline \multicolumn{2}{c}{ At ICU Admission } \\
\hline AKI characteristics \\
AKI at admission (\%) \\
Time to AKI from ICU admission (days) (median (range)) \\
sCr mg/dL at admission (median (range)) \\
BUN at admission mg/dL (SD) & $22 / 42(52)$ \\
sCr mg/dL at AKI diagnosis (median (range)) & $1.0(0-26)$ \\
BUN at AKI diagnosis mg/dL (SD) & $44(36)$ \\
Urinary output at AKI diagnosis (mL) (median (range)) & $2.1(0.8-17.6)$ \\
APACHE II at AKI diagnosis (SD) & $52(34)$ \\
sCr mg/dL at RRT start (median (range)) & $1160(0-4860)$ \\
BUN at RRT start diagnosis mg/dL (SD) & $22.7(6.1)$ \\
Urinary output at RRT start (mL) (median (range)) & $4.4(1.1-17.6)$ \\
APACHE II at RRT start (SD) & $93(52)$ \\
Patients on RRT (\%) & $375(0-4330)$ \\
Number of RRT sessions in the last 24 h before IC & $25.8(5.2)$ \\
Type of RRT (\%) & $19 / 42(45)$ \\
- SLED & $38 / 130$ \\
- HD & \\
- HDF & $32 / 38(84)$ \\
- CVVH & $4 / 38(11)$ \\
Duration RRT days (median (range)) & $1 / 38(2.5)$ \\
Still on RRT at discharge/death & $1 / 38(2.5)$ \\
\hline
\end{tabular}

AKI, Acute kidney injury; ARDS, Acute respiratory distress syndrome; BMI, body mass index; BUN, Blood urea nitrogen; $\mathrm{CAD}$, Chronic artery disease; $\mathrm{CHF}$, Chronic heart failure; $\mathrm{CKD}$, Chronic kidney disease; COPD, Chronic obstructive pulmonary disease; ICU, Intensive care unit; IMV, Invasive mechanical ventilation; NIMV, Non-invasive mechanical ventilation; RRT, Renal replacement therapy; $\mathrm{sCr}$, Serum creatinine; $\mathrm{SD}$, Standard deviation.

Table 2. Clinical characteristic on the day of IC measurement ( $n=130$ measurements).

\begin{tabular}{lc}
\hline \multicolumn{2}{c}{ Clinical Variable } \\
\hline Maximum Temperature on the Last 24 h $\left({ }^{\circ} \mathrm{C}\right)$ (Mean (SD)) \\
Vasoactive drugs $(\%)$ & $37(0.9)$ \\
- Norepinephrine & $43 / 130(33)$ \\
- Epinephrine & $43 / 43(100)$ \\
- Dopamine & $0 / 43$ \\
- Dobutamine & $0 / 43$ \\
Other drugs (\%) & $2 / 43(5)$ \\
- Barbiturates & $74 / 130(57)$ \\
- Propofol & $1 / 74(1)$ \\
- Benzodiazepines & $6 / 74(8)$ \\
- Neuromuscular blockers & $17 / 74(23)$ \\
- Morphine/Fentanyl & $2 / 74(3)$ \\
Insulin (\%) & $69 / 74(93)$ \\
Insulin IU in the last 24 h (mean (SD)) & $103 / 130(79 \%)$ \\
Blood glucose at the time of measurement (mean (SD)) & $55(36)$ \\
\hline
\end{tabular}

IC, Indirect calorimetry; SD, Standard deviation.

\subsection{Nutrition}

There were 654 days of artificial nutrition (Table 3), 45\% (294/654) on EN alone and 24\% (156/649) on enteral plus parenteral nutrition. Average energy and protein prescribed were respectively $1551 \pm 644 \mathrm{kcal}$ and $70.5 \pm 38.2 \mathrm{~g}$, while energy and protein actually delivered were $1408 \pm 651 \mathrm{kcal}$ and $63.4 \pm 35.3 \mathrm{~g}(p<0.0001$ for both comparisons). 
Table 3. Artificial nutrition characteristics.

\begin{tabular}{lc}
\hline \multicolumn{1}{c}{ Variables } \\
\hline Total Days of Nutrition & 654 \\
EN only (\%) & $294 / 654(45)$ \\
PN only (\%) & $204 / 649(31)$ \\
EN + PN (\%) & $156 / 649(24)$ \\
Prescribed energy and protein needs $(\boldsymbol{n}=\mathbf{6 5 4 )}$ & \\
- kcal/day & $1551(644)$ \\
- Protein total g/day & $70.5(38.2)$ \\
Delivered energy and protein needs $(\boldsymbol{n}=\mathbf{6 5 4})$ & \\
- kcal/day & $1408(651)^{*}$ \\
- Protein total g/day & $63.4(35.3)^{*}$ \\
Propofol (\%) & $32 / 649(5)$ \\
Energy received through somministration of propofol-kcal & $139(114)$ \\
Prokinetic drugs (\%) & $10 / 42(24)$ \\
- Domperidone (\%) & $8 / 10(80)$ \\
- Metoclopramide $(\%)$ & $4 / 10(40)$ \\
\hline
\end{tabular}

${ }^{*} p<0.0001$ vs. prescribed energy and protein. Data as mean \pm standard deviation (SD). AN: Artificial nutrition; EN: Enteral nutrition; IC: Indirect calorimetry; IMV: Invasive mechanical ventilation; PN: Parenteral nutrition; RRT: Renal replacement therapy.

\subsubsection{Indirect Calorimetry and Predictive Equations}

Table 4 shows the comparison between IC measurements, predictive equations and prescribed/delivered calories. There were 130 IC measurements over 654 days of nutrition. Mean daily energy needs by IC were $1724 \mathrm{kcal} \pm 431 \mathrm{kcal}$ (1771 $\pm 431 \mathrm{kcal}$ in ventilated patients). In general, average energy needs measured by IC were significantly higher than both the prescribed and delivered nutrient amounts (IC $1724 \mathrm{kcal} \pm 431$; prescribed $1575 \pm 672$; received $1439 \pm 680, p<0.0001$ ). No difference was observed between measured energy expenditure in patients on RRT vs. those not on RRT ( $p=0.9184)$. The predictive equation better estimating energy needs was the Penn-State equation. Bland-Altman analysis was used for a visual appraisal of agreements between predictive equations and IC (Figure 1). The wide limits of agreement in each case highlight the potential for under- or overfeeding in individual patients that might arise when these predictive equations are used. The percentage of estimates, calculated using the different equations, that fall into the "adequate", under- and overfeeding categories are shown in Table 5. Considering that AKI can cause fluid overload and that we were using the actual body weight of patients for the REE estimations, we decided to repeat the analysis considering only IC measurements and equations that were not performed during a period of fluid overload. Nineteen patients (45\%) presented fluid overload at some point during recovery, with a mean delta fluid overload (calculated with the maximum and minimum body weight during ICU stay) of $8 \pm 5.4 \mathrm{~L}$. In addition, we excluded 5 patients for whom the admission body weight was not available. Days on fluid overload corresponded to 49 IC measurements. Excluding these 49 measurements, we analyzed the remaining 81 measurements (72 measurements for ventilated patients). The results were unchanged (Table 6). For what concern the precision of the equations, no equation had the majority of estimates into the adequate category. Patients were submitted to 3 (1-11) IC and 2 (1-15) PCR measurements during ICU stay. IC measurements were performed at least twice within 7 days since ICU admission in 25 (92.6\%) of the 27 patients that had more than 1 measurement. Ten patients (37\%) had 2 measurements, 7 patients $(25.9 \%) 3,7$ patients $(25.9 \%) 4$, and 1 patient $(3.7 \%)$ had 5 measurements within this time frame. No significant differences were detected in absolute values between the first and the last IC measurements (patients with 2 measurements $($ mean \pm SEM) $1738 \pm 121$ vs. $1911 \pm 156 \mathrm{kcal} /$ day, $p=0.11$; patients with 3 measurements $1709 \pm 107$ vs. $1733 \pm 199 \mathrm{kcal} /$ day, $p=0.18$; patients with 4 measurements $1570 \pm 106 \mathrm{vs.} 1819 \pm 211 \mathrm{kcal} /$ day, $p$ $=0.36)$. Nineteen patients $(19 / 27,70 \%)$ had a second IC measurement within $48 \mathrm{~h}$ from baseline; even despite the mean difference was not statistically significant (1635 \pm 350 vs. $1705 \pm 482, p=0.42$ ), in $68 \%$ of those patients (13/19) the difference between measurements was $\geq+10 \%$ or $\leq-10 \%$, which is clinically relevant. 
Table 4. Comparison between measured, estimated, prescribed and delivered calories and proteins

\begin{tabular}{|c|c|c|c|c|c|c|}
\hline & $\begin{array}{c}\text { All Patients } \\
(n \mathrm{IC}=130 ; n \mathrm{PCR}=123)\end{array}$ & $\begin{array}{c}\text { On MV } \\
(n \text { IC }=113)\end{array}$ & $\begin{array}{c}\text { All on RRT } \\
(n \mathrm{IC}=38 ; n \text { PCR }=39)\end{array}$ & $\begin{array}{l}\text { RRT-MV } \\
(n \text { IC = 31) }\end{array}$ & $\begin{array}{c}\text { No RRT } \\
(n \text { IC }=92 ; n \text { PCR }=84)\end{array}$ & $\begin{array}{c}\text { No RRT+ MV } \\
(n \text { IC }=83)\end{array}$ \\
\hline IC & $1724(431)$ & $1771(431)$ & $1730(445)$ & $1798(469)$ & $1722(428)$ & $1762(420)$ \\
\hline \multicolumn{7}{|l|}{ Equations } \\
\hline - Harris-Benedict with stress factor & $2057(436)^{\mathrm{a}}$ & NA & $2002(277)^{\mathrm{a}}$ & NA & $2079(286)^{c}$ & NA \\
\hline - Harris-Benedict & $1582(335)^{a}$ & NA & $1540(213)^{c}$ & NA & $1599(374)^{\mathrm{a}}$ & NA \\
\hline$-25 \mathrm{kcal} / \mathrm{kg}$ & $2116(560)^{\mathrm{a}}$ & NA & $2174(463)^{a}$ & NA & $2092(596)^{a}$ & NA \\
\hline - Faisy-Fagon & NA & $2089(280)^{a}$ & NA & $2119(180)^{\mathrm{a}}$ & NA & $2079(307)^{a}$ \\
\hline - Penn State & NA & $1793(392)$ & NA & $1866(271)$ & NA & 1796 (427) \\
\hline Prescribed & $1575(672)^{a}$ & $1618(682)^{b}$ & $1593(561)$ & $1659(552)$ & $1568(716)^{b}$ & $1603(724)^{b}$ \\
\hline Received & $1439(680)^{b}$ & $1475(690)^{\mathrm{a}}$ & $1443(568)^{\mathrm{c}}$ & $1470(580)^{\mathrm{c}}$ & $1438(724)^{\mathrm{c}}$ & $1476(727)^{\mathrm{c}}$ \\
\hline ANOVA & $<0.0001$ & $<0.0001$ & $<0.0001$ & $<0.0001$ & $<0.0001$ & $<0.0001$ \\
\hline PCR g/24 h & $102.1(38.7)$ & NA & $89.5(29.3)$ & NA & $107.9(41.1)$ & NA \\
\hline nPCR $(g / k g) *$ & $1.2(1.09,0.4-2.7)$ & NA & $1.0(0.8,0.4-2.3)$ & NA & $1.3(1.2,0.6-2.7)$ & NA \\
\hline Calculated protein need $*$ & $108.3(46.2)$ & NA & $154.0(51.8)^{\mathrm{d}}$ & NA & $87.1(25.7)^{d}$ & NA \\
\hline Prescribed protein * & $76.5(37.3)^{d}$ & NA & $83.7(30.1)$ & NA & $73.2(40.0)^{d}$ & NA \\
\hline Received protein * & $69.2(35.3)^{d}$ & NA & $76.7(31.0)^{e}$ & NA & $66.2(37.0)^{d}$ & NA \\
\hline ANOVA & $<0.0001$ & NA & $<0.0001$ & NA & $<0.0001$ & NA \\
\hline
\end{tabular}

a $p<0.0001$ vs. IC. b $p<0.05$ vs. IC. ${ }^{c} p<0.01$ vs. IC. $d p<0.0001$ vs. PCR; ${ }^{e} p=0.0222$ vs. PCR RRT; * G of protein $/ 24 \mathrm{~h}$. Data expressed as mean \pm SD or mean (median, range) in the case of nPCR. IC, indirect calorimetry; MV, mechanical ventilation; NA, non applicable; RRT, renal replacement therapy. nPCR, normalized protein catabolic rate; PCR, protein catabolic rate. 
IC $x$ HB with stress factor

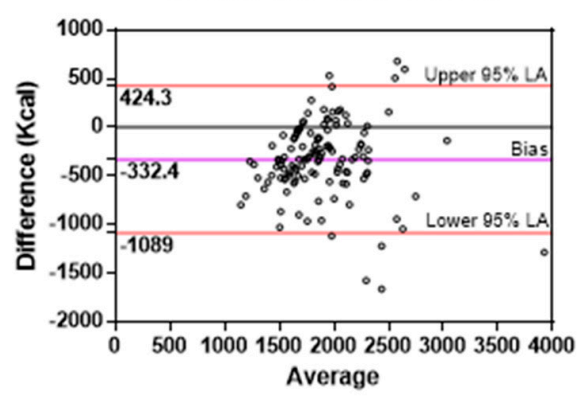

IC $\times 25 \mathrm{Kcal} / \mathrm{Kg} / \mathrm{day}$

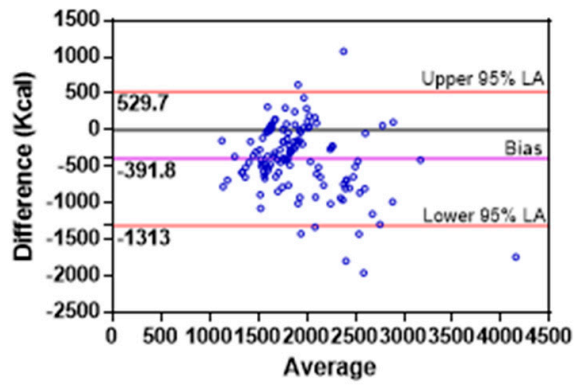

IC $\times$ Penn-State

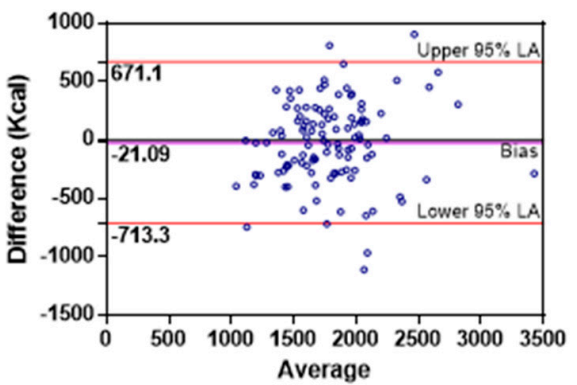

$\mathrm{IC} \times \mathrm{HB}$

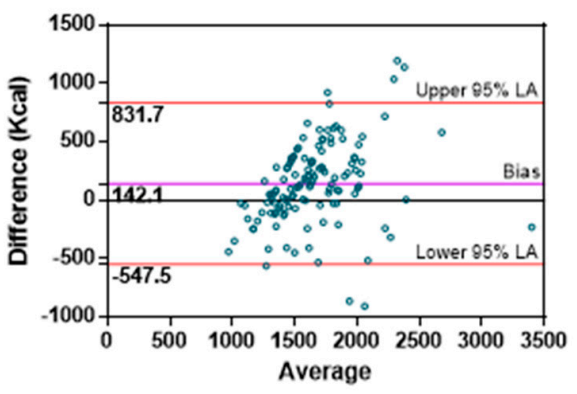

IC x Faisy-Fagon

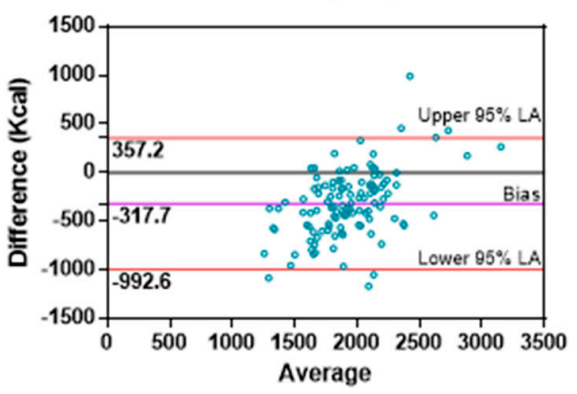

PCR $x$ calculated needs for all patients

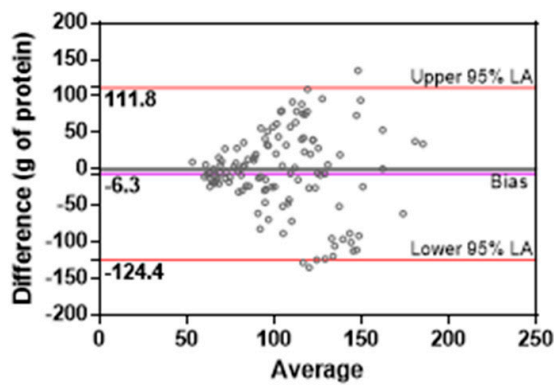

Figure 1. Bland-Altman plots of the agreements between indirect calorimetry or protein catabolic rate and predictive equations.

FF, Faisy-Fagon (ventilated patients); HB, Harris-Benedict; IC, indirect calorimetry; PCR, protein catabolic rate; Penn, Penn-State (ventilated patients).

Table 5. Number (\%) of energy expenditure estimates (calculated using the different equations) within $90 \%$ and $110 \%$ of IC values, and number (\%) of estimates that would result in under (<90\% IC) or overfeeding (>110\% IC).

\begin{tabular}{|c|c|c|c|c|c|c|c|c|c|}
\hline \multirow[t]{2}{*}{ Equation } & \multicolumn{3}{|c|}{$\%$ of Estimates $90-110 \%$ of IC } & \multicolumn{3}{|c|}{$\begin{array}{c}\% \text { of Estimates }<90 \% \text { of IC } \\
\text { (Underfeeding) }\end{array}$} & \multicolumn{3}{|c|}{$\begin{array}{c}\% \text { of Estimates }>110 \% \text { of IC } \\
\text { (Overfeeding) }\end{array}$} \\
\hline & $\begin{array}{c}\text { All } \\
\text { Patients }\end{array}$ & RRT & $\begin{array}{l}\text { No } \\
\text { RRT }\end{array}$ & $\begin{array}{c}\text { All } \\
\text { Patients }\end{array}$ & RRT & $\begin{array}{l}\text { No } \\
\text { RRT }\end{array}$ & $\begin{array}{c}\text { All } \\
\text { Patients }\end{array}$ & RRT & $\begin{array}{l}\text { No } \\
\text { RRT }\end{array}$ \\
\hline $\mathrm{HB}+30 \% \mathrm{SF}$ & 26 & 18 & 29 & 5 & 8 & 3 & 9 & 74 & 67 \\
\hline HB & 38 & 42 & 36 & 46 & 47 & 46 & 16 & 11 & 18 \\
\hline $\begin{array}{c}25 \\
\mathrm{kcal} / \mathrm{kg} / \mathrm{day}\end{array}$ & 28 & 18 & 32 & 5 & 3 & 7 & 67 & 79 & 62 \\
\hline Faisy-Fagon & 31 & 31 & 31 & 5 & 7 & 5 & 64 & 62 & 64 \\
\hline Penn-State & 40 & 38 & 40 & 27 & 24 & 27 & 34 & 38 & 32 \\
\hline
\end{tabular}

IC, indirect calorimetry; HB, Harris-Benedict equation; SF, stress factor. Faisy-Fagon and Penn-State are only for patients on mechanical ventilation. 
Table 6. Comparison between measured and estimated REE of patients not on fluid overload on the day of IC measurement.

\begin{tabular}{|c|c|c|}
\hline & All Patients $(n=81)$ & On MV $(n=72)$ \\
\hline IC & $1735(413)$ & $1791(399)$ \\
\hline \multicolumn{3}{|l|}{ Equations } \\
\hline Harris-Benedict with stress factor & $1995(462)^{a}$ & NA \\
\hline Harris-Benedict & $1535(356)^{a}$ & NA \\
\hline $25 \mathrm{kcal} / \mathrm{kg}$ & $2031(576)^{a}$ & NA \\
\hline Faisy-Fagon & NA & $2081(298)^{a}$ \\
\hline Penn State & NA & $1767(427)$ \\
\hline ANOVA & $<0.0001$ & $<0.0001$ \\
\hline
\end{tabular}

\subsubsection{Protein Catabolic Rate and Recommended Formulas}

In general, PCR values were higher than the prescribed and the actually received daily protein intakes (PCR 102.1 $g \pm 38.7$, prescribed $76.5 \pm 37.3$, received $69.2 \pm 35.3, p<0.0001$ ) (Table 4). Patients on RRT were more likely to be prescribed adequate protein amounts (PCR vs. prescribed proteins $p=0.3205)$; however, these patients actually received significantly less proteins than PCR $(p=0.02)$. Nevertheless, estimated protein needs were much higher than PCR $(154.0 \pm 51.8$ vs. $89.5 g \pm 29.3$, $p<0.0001$ ).

The Bland-Altman plot underscores the wide limits of agreement between PCR and calculated protein needs (Figure 1), leading to an increased risk of insufficient or excess protein intake.

In $46 \%$ of estimates (56/123), protein needs were overestimated. Only in 6 estimations $(15 \%)$ in the RRT group the estimated intake was able to correctly predict protein needs (within $\pm 10 \%$ of measured PCR). In the AKI subgroup of patients not on RRT protein needs were frequently underestimated $(56 \%, 47 / 84)$. Over $68 \%$ of the artificial nutrition days patients received less than $90 \%$ of PCR. Particularly, in patients not on RRT protein intake was lower than PCR over $75 \%$ of the time, while patients on RRT were underfed over $54 \%$ of the time. Adequate protein intake was given only in $13 \%$ of the measured artificial nutrition days. We also performed these analysis again considering only measurements not on fluid overload $(n=69)$. The results were unchanged (PCR $94.1 \pm 43.8$ versus Equation $90.2 \pm 35.7, p=0.61$; PCR no RRT $97.8 \pm 46.7$ vs. Equation $75.4 \pm 16.2, p=0.0023$; and PCR RRT $80.9 \pm 28.5$ vs. $143.6 \pm 36.2, p=0.0003)$. The Bland-Altman analysis continued to report wide limits of agreement (bias $3.89 \pm 56.3,95 \%$ Limits of agreement: -106.5 to 114.3 ).

\section{Discussion}

Our study suggests that in critically ill patients with AKI none of the conventional equations and formulas used to predict REE is in good agreement with actual EE measured by IC, nor protein needs were correctly estimated. Moreover, actual nutrients intakes were significantly lower as compared to both the prescribed and the measured needs.

The most ancient and widely used equation is the Harris-Benedict, developed from healthy caucasic subjects in the beginning of the 20th century [25]. In the present study, this equation was able to correctly predict EE over only $38 \%$ of time. In a very recent study on AKI patients, the same equation was the least precise, with only about $18 \%$ of cases predicting EE within $10 \%$ of the measured EE [16]. In a systematic review of the literature on the accuracy of predictive equations for critically ill patients, the Harris-Benedict equation underestimated EE and the use of correction factors was suggested to adjust EE to the current individual situation [13]. In the present study, the widely applied stress factor of 1.3 was used [31]. The use of this factor unfortunately worsened the precision of the equation when applied to patients with AKI, with only $26 \%$ of estimates between $90-110 \%$ of EE measured by IC and $69 \%$ of estimates $>110 \%$ of IC. An important factor likely to have increased the estimation error could be represented by the body weight value used for the calculations. In the case of 
patients undergoing RRT, the BW at the end of RRT was used, while for patients not on RRT the most recent BW before the IC measurement was considered for calculations. Other studies in critically ill patients also showed a low grade of agreement between Harris-Benedict equation-with and without injury factor correction - and EE measured by IC [11,12,15,16,32-35]. In addition, review studies do not recommend the use of Harris-Benedict equation, with or without injury factor, for critically ill patients $[13,36]$.

Guidelines on renal and ICU patients $[23,24,37]$ recommend $20-25 \mathrm{kcal} / \mathrm{kg} /$ day during the acute phase of the disease, and $25-30 \mathrm{kcal} / \mathrm{kg} /$ day during recovery. However, in many cases it is not mentioned if the actual, pre-admission or ideal BW should be considered. In the present study, the use of $25 \mathrm{kcal} / \mathrm{kg} /$ day calculation overestimated EE in $67 \%$ of estimates; this very fact could be explained by the use of actual BW, however, when we performed the analysis excluding measurements during fluid overload, the same equation continued to overestimate the REE of patients. In accordance with this finding, a recent study on critically ill elderly patients also showed that estimate EE based only on the relationship of Kcal per Kg of BW likely overestimated EE [38]. Thus, despite being a very simple way to predict EE, this approach is likely to increase the risk of overfeeding in ICU patients with AKI.

Unlike previous equations, the Faisy-Fagon [12] and Penn-State [13] equations were developed from EE measured in mechanically ventilated critically ill patients, and dynamic variables, such as body temperature and minute ventilation that may better reflect the metabolic state of the patient were included in the predictive formulas. In our study, the equations specific for ventilated patients had different performances. The Faisy-Fagon equation was the least precise, with $64 \%$ of estimates on the overfeeding category, while Penn-State had $40 \%$ of estimates between $90-110 \%$ of values obtained by IC. In a recent study on AKI patients that used the admission BW for the calculations, those equations underestimated EE [16], again underscoring the importance of the reference BW chosen for estimation. Although the Penn-State was more accurate in our patients, it is not precise enough and its wide limits of agreement highlight the potential to under or overfeed individual patients (Figure 1). Therefore, it cannot be recommended for mechanically ventilated critically ill patients with AKI. A major problem is that no consensus exist on which BW should be utilized for EE estimation, thus explaining at least in part the differences observed in our study between measured and calculated needs, and also the dysomogeneity found among different studies. In our study, the actual BW after RRT was used; however, in some cases the patient's weight at admission was used due to lack of BW availability during ICU stay. Nevertheless, also the analysis of the IC measurements that occurred in days with no fluid overload did not change our results. A very recent study on 205 critically ill patients compared REE measured by IC with Harris-Benedict equation calculated with 3 different reference weights (actual, ideal and predicted BW) [39]. The use of actual BW resulted in the most accurate predicted REE; however, the limits of agreement between the equation and IC measurements were very wide [39].

Finally, whether only one IC measurement at the beginning of recovery is enough to tailor nutritional prescriptions during ICU stay is still an open question. In our study there was no difference between energy measurements performed at the beginning of ICU stay and within one week, nor within $48 \mathrm{~h}$, despite a vast majority of patients (68\%) presenting with differences greater than $\pm 10 \%$, which could be clinically relevant. A retrospective study on 1171 critically ill patients found a significant $(p<0.0001)$ between-day difference, however the difference lost significance after excluding the first 2 days of hospitalization [40]. An expert position paper on IC in critically ill patients [9] states that energy expenditure of critically ill patients is very dynamic and depends on the phase and the severity of illness, treatment and extended bedrest. The same concept holds true for AKI patients [23,24]. Thus, it is recommended that, whenever the clinical condition of the patient is changing, IC should be repeated.

In our study, the formulas used for the estimation of protein needs had different performances in patients on RRT and in patients not on RRT. Because patients undergoing RRT are likely to have more fluid overload, and since BW at the end of RRT was used for the calculations, protein catabolic 
rate values in these patients were lower than the estimated ones. However, excluding measurements obtained during fluid overload, the results were unchanged (all patients, patients not needing RRT, and patients undergoing RRT). Normalized PCR of $1.5-2.1 \mathrm{~g} / \mathrm{kg} /$ day have been obtained by the urea kinetic method in small groups of patients with AKI on different modalities of RRT [10,17-21]. However, different BW were considered for protein intake normalization in these studies. In two studies the lowest BW measured during ICU stay was used [19,21], in another the actual BW [20], and in the remaining 3 studies no information was available on which was the reference BW $[10,17,18]$. Even Guidelines not always clearly specify which BW should be considered for protein needs estimation in critically ill patients with AKI (23-24). In the present study, actual BW was preferably used, and it was the same weight used for the EE estimation. Thus, the use of different BW could explain most of the differences in protein needs estimation, underlying the importance to obtain PCR in critically ill patients. As a matter of fact, recent studies suggest that adequate protein intake correlates to better outcomes in critically ill [26,41-43] and AKI patients [21]; in addition, negative nitrogen balance was identified as a predictor of death in AKI patients [44].

The present study has some limitations. First of all, the sample size was relatively small, however the number of measurements performed was high, which increased the accuracy of the Bland-Altman analysis. Second, the reference BW used to estimate REE and protein needs was the actual BW. The use of the actual BW might have influenced the calculated protein and energy needs since AKI patients frequently suffer from fluid overload, however different studies used different BW, and there is no clear recommendation regarding which BW should be considered when prescribing artificial nutrition in critically ill patients with AKI. Third, the RRT modality that was used more frequently was SLED ( $84 \%$ of the computed treatments). In our unit, SLED protocol is based on trisodium citrate as anticoagulant [45]. It is well known that the use of trisodium citrate can provide hidden non nutritional calories (NNC) that should be considered during artificial nutrition prescription, in this study we did not consider the amount of calories provided by citrate during SLED. However, in a previous study published by our group that investigated the safety of citrate as anticoagulant for SLED, the average amount of NNC provided with our protocol was $90 \mathrm{kcal} / \mathrm{SLED}$ session of $8 \mathrm{~h}$ [45]. Probably, the statistical significance of the difference between received and measured energy needs would have been lost for the RRT subgroup if we had considered the NNC from citrate anticoagulation during SLED. One last consideration that should be made regarding the limitations of our study is that we did not measure the amount of amino acids lost during RRT to be considered in the actual protein needs in addition to the PCR. A recent study on five patients undergoing SLED identified a median loss of $15.7 \mathrm{~g}$ of amino acids per treatment [46]. This information in our study would probably not change the statistical significance of the difference between actual protein needs and estimated protein needs, and would increase the gap between actually received and protein need, only reinforcing the need for accurate protein need determination and prescription in the clinical practice.

\section{Conclusions}

In conclusion, the use of predictive equations and formulas in order to guide the nutritional approach is not accurate in critically ill patients with AKI in the ICU and should be discouraged. Whenever possible, critically ill patients with AKI should have their feeding regimen tailored by actual measurements of energy and protein needs.

Supplementary Materials: The following are available online at www.mdpi.com/2072-6643/9/8/802/s1, Table S1: Equations used for the estimation of resting energy expenditure.

Acknowledgments: Alice Sabatino is the recipient of a research fellowship from the University of Parma for the subproject: Valutazione del fabbisogno calorico mediante calorimetria indiretta nei pazienti con sepsi e insufficienza renale acuta sottoposti a terapia sostitutiva della funzione renale con metodiche immunomodulanti ("Assessment of energy needs by indirect calorimetry in patients with sepsis and acute kidney injury undergoing renal replacement therapy with immunomodulatory methods") (Progetto Giovani Ricercatori Bando 2011-2012 funding number: Prot. 2010J4458Z). 
Author Contributions: Alice Sabatino and Enrico Fiaccadori designed the protocol and wrote the paper. Alice Sabatino, Miriam Theilla, Moran Hellerman, Pierre Singer and Maria Barbagallo participated on data collection, data discussion and interpretation. Alice Sabatino, Giuseppe Regolisti and Umberto Maggiore performed statistical analysis. All authors have read and approved the final manuscript.

Conflicts of Interest: The authors declare no conflict of interest.

\section{References}

1. Li, P.K.; Burdmann, E.A.; Mehta, R.L. Acute kidney injury: Global health alert. Kidney Int. 2013, 83, 372-376. [CrossRef] [PubMed]

2. Lameire, N.H.; Bagga, A.; Cruz, D.; de Maeseneer, J.; Endre, Z.; Kellum, J.A.; Liu, K.D.; Mehta, R.L.; Pannu, N.; Biesen, W.V.; et al. Acute kidney injury: An increasing global concern. Lancet 2013, 382, 170-179. [CrossRef]

3. Susantitaphong, T.; Cruz, D.N.; Cerda, J.; Abulfaraj, M.; Alqahtani, F.; Koulouridis, I.; Jaber, B.L. World incidence of AKI: A meta-analysis. Clin. J. Am. Soc. Nephrol. 2013, 8, 1482-1493. [CrossRef] [PubMed]

4. Uchino, S.; Bellomo, R.; Morimatsu, H.; Morgera, S.; Schetz, M.; Tan, I.; Bouman, C.; Macedo, E.; Gibney, N.; Tolwani, A.; et al. Continuous renal replacement therapy: A worldwide practice survey. The beginning and ending supportive therapy for the kidney (B.E.S.T. kidney) investigators. Intensive Care Med. 2007, 33, 1563-1570. [CrossRef] [PubMed]

5. Fiaccadori, E.; Lombardi, M.; Leonardi, S.; Rotelli, C.F.; Tortorella, G.; Borghetti, A. Prevalence and clinical outcome associated with preexisting malnutrition in acute renal failure: A prospective cohort study. J. Am. Soc. Nephrol. 1999, 10, 581-593. [PubMed]

6. Fiaccadori, E.; Regolisti, G.; Maggiore, U. Specialized nutritional support interventions in critically ill patients on renal replacement therapy. Curr. Opin. Clin. Nutr. Metab. Care 2013, 16, 217-224. [CrossRef] [PubMed]

7. Fiaccadori, E.; Sabatino, A.; Morabito, S.; Bozzoli, L.; Donadio, C.; Maggiore, U.; Regolisti, G. Hyper/Hypoglycemia and acute kidney injury in critically ill patients. Clin. Nutr. 2016, 35, 317-321. [CrossRef] [PubMed]

8. Bellomo, R.; Cass, A.; Cole, L.; Finfer, S.; Gallagher, M.; Lee, J.; Lo, S.; McArthur, C.; McGuinness, S.; Myburgh, J.; et al. Calorie intake and patient outcomes in severe acute kidney injury: Findings from the randomized evaluation of normal vs. augmented level of replacement therapy (RENAL) study trial. Crit. Care 2014, 18, R45. [CrossRef] [PubMed]

9. Oshima, T.; Berger, M.M.; de Waele, E.; Guttormsen, A.B.; Heidegger, C.-P.; Hiesmayr, M.; Singer, P.; Wernerman, J.; Pichard, C. Indirect calorimetry in nutritional therapy A position paper by the ICALIC study group. Clin. Nutr. 2017, 36, 651-662. [CrossRef] [PubMed]

10. Fiaccadori, E.; Maggiore, U.; Rotelli, C.; Giacosa, R.; Picetti, E.; Parenti, E.; Meschi, T.; Borghi, L.; Tagliavini, D.; Cabassi, A. Effects of energy intakes on nitrogen balance in patients with acute renal failure: A pilot study. Nephrol. Dial. Transpl. 2005, 20, 1976-1980. [CrossRef] [PubMed]

11. Kross, E.K.; Sena, M.; Schmidt, K.; Stapleton, R.D. A comparison of predictive equations of energy expenditure and measured energy expenditure in critically ill patients. J. Crit. Care 2012, 27, e5-e12. [CrossRef] [PubMed]

12. Faisy, C.; Guerot, E.; Diehl, J.L.; Labrousse, J.; Fagon, J.Y. Assessment of resting energy expenditure in mechanically ventilated patients. Am. J. Clin. Nutr. 2003, 78, 241-249. [PubMed]

13. Frankenfield, D.; Hise, M.; Malone, A.; Russell, M.; Gradwell, E.; Compher, C. Prediction of resting metabolic rate in critically ill adult patients: Results of a systematic review of the evidence. J. Am. Diet Assoc. 2007, 107, 1552-1561. [CrossRef] [PubMed]

14. Frankenfield, D.C.; Coleman, A.; Alam, S.; Cooney, R.N. Analysis of estimation methods for resting metabolic rate in critically ill adults. JPEN J. Parenter. Enter. Nutr. 2009, 33, 27-36. [CrossRef] [PubMed]

15. MacDonald, A.; Hildebrandt, L. Comparison of formulaic equations to determine energy expenditure in the critically ill patient. Nutrition 2003, 19, 233-239. [CrossRef]

16. De Góes, C.R.; Berbel-Bufarah, M.N.; Sanches, A.C.; Xavier, P.S.; Balbi, A.L.; Ponce, S. Poor agreement between predictive equations of energy expenditure and measured energy expenditure in critically ill acute kidney injury patients. Ann. Nutr. Metab. 2016, 68, 276-284. [CrossRef] [PubMed] 
17. Chima, C.S.; Meyer, L.; Hummel, A.C.; Bosworth, C.; Heyka, R.; Paganini, E.P.; Werynski, A. Protein catabolic rate in patients with acute renal failure on continuous arteriovenous hemofiltration and total parenteral nutrition. J. Am. Soc. Nephrol. 1993, 3, 1516-1521. [PubMed]

18. Macias, W.L.; Alaka, K.J.; Murphy, M.H.; Miller, M.E.; Clark, W.R.; Mueller, B.A. Impact of the nutritional regimen on protein catabolism and nitrogen balance in patients with acute renal failure. JPEN J. Parenter. Enter. Nutr. 1996, 20, 56-62. [CrossRef] [PubMed]

19. Leblanc, M.; Garred, L.J.; Cardinal, J.; Pichette, V.; Nolin, L.; Ouimet, D.; Geadah, D. Catabolism in critical illness: Estimation from urea nitrogen appearance and creatinine production during continuous renal replacement therapy. Am. J. Kidney Dis. 1998, 32, 444-453. [CrossRef] [PubMed]

20. Marshall, M.R.; Golper, T.A.; Shaver, M.J.; Alam, M.G.; Chatoth, D.K. Urea kinetics during sustained low-efficiency dialysis in critically ill patients requiring renal replacement therapy. Am. J. Kidney Dis. 2002, 39, 556-570. [CrossRef] [PubMed]

21. Kritmetapak, K.; Peerapornratana, S.; Srisawat, N.; Somlaw, N.; Lakananurak, N.; Dissayabutra, T.; Phonork, C.; Leelahavanichkul, A.; Tiranathanagul, K.; Susantithapong, P.; et al. The impact pf macro-and micronutrients on predicting outcomes of critically ill patients requiring continuous renal replacement therapy. PLoS ONE 2016, 11, e0156634. [CrossRef] [PubMed]

22. Khwaja, A. KDIGO Clinical practice guidelines for acute kidney injury. Kidney Int. 2012, 2, 1-138. [CrossRef] [PubMed]

23. Cano, N.; Fiaccadori, E.; Tesinsky, P.; Toigo, G.; Druml, W.; Kuhlmann, M.; Mann, H.; Hörl, W.H. ESPEN guidelines on enteral nutrition: Adult renal failure. Clin. Nutr. 2006, 25, 295-310. [CrossRef] [PubMed]

24. Cano, N.; Aparicio, M.; Brunori, G.; Carrero, J.J.; Cianciaruso, B.; Fiaccadori, E.; Lindholm, B.; Teplan, V.; Fouque, D.; Guarnieri, G. ESPEN guidelines on parenteral nutrition: Adult renal failure. Clin. Nutr. 2009, 28, 401-414. [CrossRef] [PubMed]

25. Harris, J.A.; Benedict, F.G. A biometric study of human basal metabolism. Proc. Natl. Acad. Sci. USA 1918, 4, 370-373. [CrossRef] [PubMed]

26. Garred, L.J. Dialysate-based kinetic modeling. Adv. Ren. Replace. Ther. 1995, 2, 305-318. [CrossRef]

27. Bland, J.M.; Altman, D.G. Statistical methods for assessing agreement between two methods of clinical measurement. Lancet 1986, 1, 307-310. [CrossRef]

28. Boullata, J.; Williams, J.; Cottrell, F.; Hudson, L.; Compher, C. Accurate determination of energy needs in hospitalized patients. J. Am. Diet Assoc. 2007, 107, 393-401. [CrossRef] [PubMed]

29. Reid, C.L. Poor agreement between continuous measurements of energy expenditure and routinely used prediction equations in intensive care unit patients. Clin. Nutr. 2007, 26, 649-657. [CrossRef] [PubMed]

30. Robins, K.; Stankorb, S.M.; Salgueiro, M. Energy expenditure in acute posttraumatic amputation: Comparison of four methods for assessment. Nutr. Clin. Pract. 2013, 28, 758-765. [CrossRef] [PubMed]

31. Long, C.L.; Schaffel, N.; Geiger, J.W.; Schiller, W.R.; Blackmore, W.S. Metabolic response to injury and illness: Estimation of energy and protein needs from indirect calorimetry and nitrogen balance. JPEN J. Parenter. Enter. Nutr. 1979, 3, 452-456. [CrossRef] [PubMed]

32. Casati, A.; Colombo, S.; Leggieri, C.; Muttini, S.; Capocasa, T.; Gallioli, G. Measured versus calculated energy expenditure in pressure support ventilated ICU patients. Minerva Anestesiol. 1996, 62, 165-170. [PubMed]

33. O'Leary-Kelley, C.M.; Puntillo, K.A.; Barr, J.; Stotts, N.; Douglas, M.K. Nutritional adequacy in patients receiving mechanical ventilation who are fed enterally. Am. J. Crit. Care 2005, 14, 222-231. [PubMed]

34. Hickmann, C.E.; Roeseler, J.; Castanares-Zapatero, D.; Herrera, E.I.; Mongodin, A.; Laterre, P.F. Energy expenditure in the critically ill performing early physical therapy. Intensive Care Med. 2014, 40, 548-555. [CrossRef] [PubMed]

35. De Waele, E.; Spapen, H.; Honoré, P.M.; Mattens, S.; van Gorp, V.; Diltoer, M.; Huyghens, L. Introducing a new generation indirect calorimeter for estimating energy requirements in adult intensive care unit patients: Feasibility, practical considerations, and comparison with a mathematical equation. J. Crit. Care 2013, 28, e1-e6. [CrossRef] [PubMed]

36. Walker, R.N.; Heuberger, R.A. Predictive equations for energy needs for the critically ill. Respir. Care 2009, 54, 509-521. [PubMed]

37. Kreymann, K.G.; Berger, M.M.; Deutz, N.E.; Hiesmayr, M.; Jolliet, P.; Kazandjiev, G.; Nitenberg, G.; van den Berghe, G.; Wernerman, J.; Ebner, C.; et al. ESPEN guidelines on enteral nutrition: Intensive care. Clin. Nutr. 2006, 25, 210-223. [CrossRef] [PubMed] 
38. Segadilha, N.L.; Rocha, E.E.; Tanaka, L.M.; Gomes, K.L.; Espinoza, R.E.; Peres, W.A. Energy expenditure in critically ill elderly patients: Indirect calorimetry vs. predictive equations. JPEN J. Parenter. Enter. Nutr. 2016. [CrossRef] [PubMed]

39. Picolo, M.F.; Lago, A.F.; Menegueti, M.G.; Nicolini, E.A.; Basile-Filho, A.; Nunes, A.A.; Martins-Filho, O.A.; Auxiliadora-Martins, M. Harris-Benedict equation and resting energy expenditure estimates in critically ill ventilator patients. Am. J. Crit. Care 2016, 25, e21-e29. [CrossRef] [PubMed]

40. Zusman, O.; Theilla, M.; Cohen, J.; Kagan, I.; Bendavid, I.; Singer, P. Resting energy expenditure, calorie and protein consumption in critically ill patients: A retrospective cohort study. Crit. Care 2016, 20, 367. [CrossRef] [PubMed]

41. Allingstrup, M.J.; Esmailzadeh, N.; Wilkens Knudsen, A.; Espersen, K.; Hartvig Jensen, T.; Wiis, J.; Perner, A.; Kondrup, J. Provision of protein and energy in relation to measured requirements in intensive care patients. Clin. Nutr. 2012, 31, 462-468. [CrossRef] [PubMed]

42. Van Strack, S.R.J.; Weijs, P.J.; Koopmans, R.H.; Sauerwein, H.P.; Beishuizen, A.; Girbes, A.R. Optimal nutrition during the period of mechanical ventilation decreases mortality in critically ill, long-term acute female patients: A prospective observational cohort study. Crit. Care 2009, 13, R132. [CrossRef] [PubMed]

43. Singer, P.; Hiesmayr, M.; Biolo, G.; Felbinger, T.W.; Berger, M.M.; Goeters, C.; Kondrup, J.; Wunder, C.; Pichard, C. Pragmatic approach to nutrition in the ICU: Expert opinion regarding which calorie protein target. Clin. Nutr. 2014, 33, 246-251. [CrossRef] [PubMed]

44. Bufarah, M.N.B.; de Góes, C.R.; Oliveira, M.C.; Ponce, D.; Balbi, A.L. Estimating catabolism: A possible tool for nutritional monitoring of patients with acute kidney injury. J. Ren. Nutr. 2017, 27, 1-7. [CrossRef] [PubMed]

45. Fiaccadori, E.; Regolisti, G.; Cademartiri, C.; Cabassi, A.; Picetti, E.; Barbagallo, M.; Gherli, T.; Castellano, G.; Morabito, S.; Maggiore, U. Efficacy and safety of a citrate-based protocol for sustained low-efficiency dialysis in AKI using standard dialysis equipment. Clin. J. Am. Soc. Nephrol. 2013, 8, 1670-1678. [CrossRef] [PubMed]

46. Umber, A.; Wolley, M.J.; Golper, T.A.; Shaver, M.J.; Marshall, M.R. Amino acid losses during sustained low efficiency dialysis in critically ill patients with acute kidney injury. Clin. Nephrol. 2014, 81, 93-99. [CrossRef] [PubMed] 